\title{
Analgesic effect of single-shot ropivacaine at different layers of the surgical site in primary total hip arthroplasty: a randomised, controlled, observer-blinded study
}

Qiang Xiao ${ }^{1,2+}$, Bing Xu ${ }^{1 \dagger}$, Haoyang Wang ${ }^{2}$, Zhenyu Luo ${ }^{2}$, Mingcheng Yuan², Zongke Zhou ${ }^{2 *}$ and Fuxing Pei ${ }^{2}$

\begin{abstract}
Objectives: The aim of this study was to evaluate the efficacy of local infiltration anaesthesia (LIA) during primary total hip arthroplasty (THA) via a posterolateral approach under general anaesthesia and to compare the efficacy of LIA in all layers with LIA in the deep and superficial fascia.

Patients and methods: One hundred twenty patients were randomised into three groups: LIA in the deep and superficial fascia (group A), LIA in all layers (group B) and the control (group C). The primary outcomes were the visual analogue scale (VAS) pain scores at rest and on movement within $72 \mathrm{~h}(\mathrm{~h})$ postoperatively. The secondary outcomes included opioid consumption, patient satisfaction, range of motion (ROM), straight leg raise completion rate, length of hospital stay, opioid-related side effects and wound complications. We followed the patients until 6 months after discharge.
\end{abstract}

Results: At 2 and 6 h, groups A and B had lower resting VAS scores than group C $(p<0.01)$; at 12 h, group B had a lower resting VAS score than group $C(p<0.05)$. At 6 and $12 \mathrm{~h}$, the movement VAS scores in groups $A$ and $B$ were lower than those in group $C(p<0.01)$. Groups A and B had similar VAS scores during the observation period. Groups A and B had higher levels of patient satisfaction than group C ( $p=0.03$ and $p=0.018$, respectively). Opioid consumption was similar in the three groups. There were no significant differences in the other secondary outcomes amongst the three groups. No difference was found in hip rehabilitation or chronic pain during the follow-up period.

Conclusion: Single-shot LIA with ropivacaine alone reduces the pain score during the first 12 postoperative hours and improves patients' satisfaction with THA. LIA in the deep and superficial fascia and LIA in all layers have similar analgesic effects. LIA in the deep and superficial fascia may be an alternative method to LIA in all layers.

Keywords: Total hip arthroplasty, Local infiltration anaesthesia, Postoperative pain

\footnotetext{
* Correspondence: zhouzongke@scu.edu.cn

${ }^{\dagger}$ Qiang Xiao and Bing Xu contributed equally to this work.

2Department of Orthopedics, West China Hospital/West China School of Medicine, Sichuan University, 37\# Wuhou Guoxue Road, Chengdu 610041, People's Republic of China

Full list of author information is available at the end of the article
}

(c) The Author(s). 2021 Open Access This article is licensed under a Creative Commons Attribution 4.0 International License, which permits use, sharing, adaptation, distribution and reproduction in any medium or format, as long as you give appropriate credit to the original author(s) and the source, provide a link to the Creative Commons licence, and indicate if changes were made. The images or other third party material in this article are included in the article's Creative Commons licence, unless indicated otherwise in a credit line to the material. If material is not included in the article's Creative Commons licence and your intended use is not permitted by statutory regulation or exceeds the permitted use, you will need to obtain permission directly from the copyright holder. To view a copy of this licence, visit http://creativecommons.org/licenses/by/4.0/ The Creative Commons Public Domain Dedication waiver (http://creativecommons.org/publicdomain/zero/1.0/) applies to the data made available in this article, unless otherwise stated in a credit line to the data. 


\section{Introduction}

Postoperative pain after total hip arthroplasty (THA) can increase the risk of postoperative complications, length of hospital stay and cost; thus, it influences patients' satisfaction [1]. In China, approximately $8 \%$ of patients are not satisfied with THA, and pain is the most important factor influencing that dissatisfaction [2]. Multimodal analgesia regimens are widely used to manage perioperative pain for THA, and local infiltration anaesthesia (LIA) is one of the main components [1]. The LIA technique used during THA was first introduced by Kerr and Kohan [3], who used a "cocktail" that was a mixture of ropivacaine, ketorolac acid and adrenaline to achieve local infiltration in all layers at the surgical site and an indwelling catheter in the wound for the continuous injection of analgesics after the operation. After that, several randomised controlled trials (RCTs) on single-shot LIA in THA were conducted; the outcomes of these RCTs were controversial, and the local analgesics (LAs) used in these RCTs were not all the same [4-14]. Some of these studies $[6,8,10-13]$ used cocktails of drugs for the infiltration, and other studies $[9,14]$ used single drugs. Some of these studies $[6,10,12,14]$ showed that single-shot LIA could reduce early postoperative pain and/or opioid use after THA, and other studies [8, 9, 11, 13] showed that single-shot LIA did not provide additional analgesic effects in THA managed by a multimodal analgesia regimen. Previous studies showed that a lateral femoral cutaneous nerve block could relieve the postoperative pain from a posterolateral approach THA and reduce the use of opioids after femoral neck fracture surgery performed through a lateral incision [15-17]. This suggests that LIA of the deep and superficial fascia at the surgical site may relieve postoperative pain after the posterolateral approach because the incision is located in the area of lateral femoral cutaneous nerve innervation.

Therefore, we performed an RCT to evaluate the efficacy of single-shot LIA with ropivacaine alone in primary THA performed via a posterolateral approach under general anaesthesia and to compare the efficacy of LIA in all layers with that of LIA in the deep and superficial fascia.

\section{Patients and methods}

Prior to patient enrolment, this trial was registered in the Chinese Clinical Trial Registry (identifier ChiCTR1800016700, registration date 18 June 2018, http://www.chictr.org.cn/edit.aspx?pid=28384\&htm $=4$ ) and was approved by the Ethics Committee and Institutional Review Board of West China Hospital, Sichuan University. Written informed consent was obtained from all patients before surgery. The study was conducted at the Department of Joint Surgery of West China Hospital,
Sichuan University, according to the CONSORT (Consolidated Standards of Reporting Trials) Statement. The clinical study was performed in accordance with the Declaration of Helsinki on ethical principles for medical research involving human subjects.

We recruited consecutive patients aged $18-80$ years with an American Society of Anesthesiologists Physical Status I-III who were scheduled for primary unilateral THA via a posterolateral approach under general anaesthesia. The exclusion criteria included a known allergy, contraindication to or dependence on drugs used in the protocol, a history of alcohol addiction, reoperation, severe liver and kidney dysfunction, pregnancy or breastfeeding, refusal to participate and failure to complete the related indicators.

Patients were randomly divided into three groups: LIA in the deep and superficial fascia (group A), LIA in all layers (group B) and control (group C). A random sequence was generated by a computer and hidden in consecutive numbered, sealed, opaque envelopes by research assistants who did not participate in the data analysis. The envelope was opened prior to surgery, and the LA was prepared by operating room nurses not involved with patient care or evaluation. Patients, anaesthesiologists, care providers, analgesic drug managers and data collectors were all blinded to the allocation sequence. The surgeon (Z-K. Z) who performed the LIA could not be blinded, but he was not involved in the data collection or postoperative management related to this trial.

All patients underwent standardised general anaesthesia. All THAs were performed by the same senior surgeon (Z-K. Z) using a posterolateral approach and a single brand of cementless components (DePuy Synthes). No postoperative drain was used. Group A and group B received infiltration performed by the surgeon (Z-K. Z) with $80 \mathrm{ml}$ of $0.25 \%$ ropivacaine (Naropin, AstraZeneca) solution. The infiltration technique described by Kerr and Kohan was used [3], but we used single-shot infiltration. Group A received LIA of the deep and superficial fascia. After suturing the deep fascia, $40 \mathrm{ml}$ of solution was infiltrated into the deep fascia, and the other $40 \mathrm{ml}$ of solution was infiltrated into the superficial fascia. In group B, $40 \mathrm{ml}$ of solution was infiltrated into the deep tissues, including the tissues around the rim of the acetabulum, external rotators and gluteus tendon. The remaining $40 \mathrm{ml}$ of solution was infiltrated into the superficial tissues, including the fascia, subcutaneous tissues and skin. No LIA was performed in group C.

All patients received the same analgesic protocol. $\mathrm{Pa}$ tients received celecoxib (Celebrex, Pfizer) $200 \mathrm{mg}$ orally every $12 \mathrm{~h}$ for pre-emptive analgesia after admission and celecoxib $200 \mathrm{mg}$ orally every $12 \mathrm{~h}$ for postoperative pain. When the VAS score was $\geq 4$ (visual analogue 
scale, $0=$ no pain, $10=$ worst pain) and $\leq 6$, patients received oxycodone hydrochloride prolonged-release tablets (OxyContin, Mundipharma) $10 \mathrm{mg}$ orally every $12 \mathrm{~h}$ as a rescue medicine. When the VAS score was $>6$, a subcutaneous injection of $5 \mathrm{mg}$ of morphine was administered immediately as a rescue medicine. After discharge, patients continued to receive $200 \mathrm{mg}$ celecoxib orally every $12 \mathrm{~h}$ for 2 weeks, and then we used analgesics according to patient need. The remaining aspects of perioperative management were the same. All patients were treated with $1.5 \mathrm{~g}$ cefuroxime before the skin incision and then $1.5 \mathrm{~g}$ every $8 \mathrm{~h}$ after the operation for $24 \mathrm{~h}$. All patients were given 2000 Axa IU of enoxaparin sodium (Clexane, Sanofi) $6 \mathrm{~h}$ after the operation, and 4000 Axa IU was given daily from the first day after the operation until discharge. After discharge, $10 \mathrm{mg}$ of rivaroxaban (Xarelto, Bayer) was given once a day for 10 days. The rehabilitation nurses guided the patients to perform active ROM exercises and strength training postoperatively, and the patients began walking with crutches on the first day after the operation. The discharge criteria mainly included functional recovery and pain relief: the ability to walk more than $30 \mathrm{~m}$ with crutches, the ability to climb stairs, the ability to dress, the ability to go to the bathroom independently, a VAS score lower than 3 at rest and a VAS score lower than 5 during movement.

The primary outcome was the VAS pain score at rest and during movement. The resting VAS score was assessed at 2, 6, 12, 24, 36, 48, 60 and $72 \mathrm{~h}$ after the operation, and the movement VAS score was assessed at 6 , $12,24,36,48,60$ and $72 \mathrm{~h}$ after the operation.

The secondary outcomes included opioid consumption, patient satisfaction, ROM of the hip on postoperative day 2 , the number of patients completing the straight leg raise at postoperative day 1 , the length of hospital stay, opioid-related side effects (nausea and vomiting, urinary retention and pruritus) and wound complications. In addition, we followed up with the patients at 2 weeks, 3 months and 6 months after the operation to assess hip pain, hip function, wound complications and quality of life. Opioid consumption was uniformly converted to equivalents of oral morphine for the statistical analysis. The conversion factor was as follows: $10 \mathrm{mg}$ of subcutaneously injected morphine was equal to $30 \mathrm{mg}$ of oral morphine, and $10 \mathrm{mg}$ of oral OxyContin was equal to $20 \mathrm{mg}$ of oral morphine $[18,19]$.

\section{Statistical analyses}

Continuous data are shown as the means and standard deviations (SDs). Categorical data are presented as numbers and percentages. One-way analysis of variance (ANOVA) with post hoc Bonferroni tests were used for normally distributed continuous variables, and the
Kruskal-Wallis test with the post hoc Nemenyi test were used for skewed continuous variables. Chi-square or Fisher tests were used for categorical variables. Statistical significance was set at $p<0.05$. Statistical analyses were performed with SPSS (version 22.0; IBM).

The sample size was calculated by the G Power Version 3.1.9 (Franz Faul; Uni Kiel, Germany) software. A pilot study was performed with 15 patients (5 in each group), and the resting VAS scores in the three groups at 6 postoperative hours were 2.2, 2.0 and 2.6, with a SD was 0.704 , and then the effect size $f=0.35$ was calculated. According to this effect size, an alpha level (2 tailed) $=0.05$, and power $=0.95,35$ patients would be needed in each arm of the study using a fixed effect oneway ANOVA design. Assuming a 15\% loss to follow-up, 40 patients were enrolled in each arm.

\section{Results}

From July 2018 to December 2018, a total of 142 patients scheduled for primary unilateral THA were assessed for eligibility. Twenty-two patients were excluded: 15 patients did not meet the inclusion criteria, 5 patients declined to participate and 2 patients had their surgeries cancelled. Therefore, there were 120 patients randomised to the three groups. One patient in group $\mathrm{C}$ died 2 weeks after discharge due to a cause (pulmonary hypertension) unrelated to THA. The remaining $119 \mathrm{pa}-$ tients completed the trial (Fig. 1). No significant differences were identified amongst the groups with respect to the patients' baseline demographic variables and perioperative characteristics (Table 1).

At 2 and 6 postoperative hours, the resting VAS scores in groups A and B were significantly lower than those in group $C(p<0.01$, and $p<0.001$, respectively), with no significant differences between groups $\mathrm{A}$ and $\mathrm{B}$; at 12 postoperative hours, the VAS score in group B was significantly lower than that in group $C(p<0.05)$, with no significant difference between groups $\mathrm{A}$ and $\mathrm{B}$ or groups $\mathrm{A}$ and $\mathrm{C}(p>0.05)$ (Tables 2, 3).

Similarly, at 6 and 12 postoperative hours, the movement VAS scores in groups A and B were significantly lower than those in group $C(p<0.01$, and $p<0.001$, respectively), with no significant differences between groups A and B $(p>0.05)$ (Tables 2,3$)$. At the rest of the time points during the study period, no significant differences were found in resting and movement VAS scores amongst the three groups (Table 2).

Groups A and B had higher levels of patient satisfaction with pain control than group $\mathrm{C}(p=0.03$, and $p=$ 0.018 , respectively), and more patients in groups $\mathrm{A}$ and $\mathrm{B}$ than in group $\mathrm{C}$ could complete the straight leg raise test at postoperative day $1(p=0.004$, and $p=0.032$, 


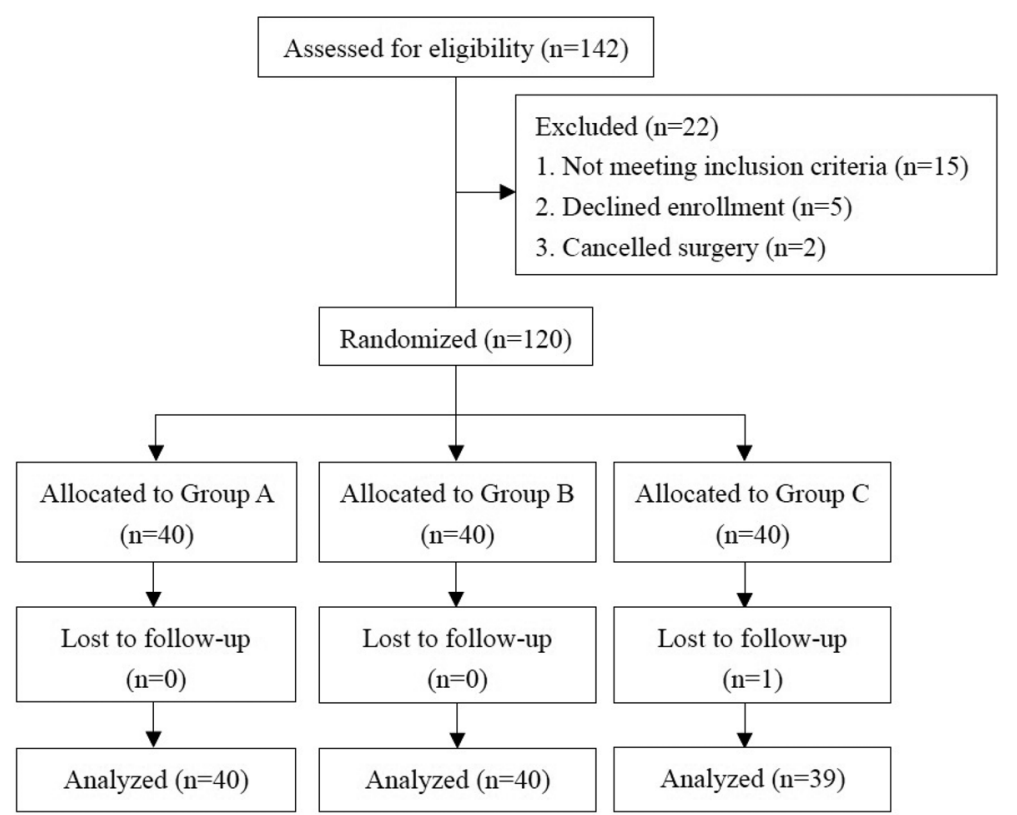

Fig. 1 CONSORT (Consolidated Standards of Reporting Trials) flow diagram. Group A, LIA in the deep and superficial fascia; group B, LIA in all layers, group C, the control

Table 1 Demographic variables and perioperative characteristics

\begin{tabular}{|c|c|c|c|c|}
\hline Variables & Group A $(n=40)$ & Group B $(n=40)$ & Group C $(n=39)$ & $P$ values ${ }^{\dagger}$ \\
\hline Age (years) & $56.0 \pm 13.2$ & $55.2 \pm 15.2$ & $56.4 \pm 13.6$ & 0.926 \\
\hline Sex, M/F & $22 / 18$ & $27 / 13$ & $16 / 23$ & 0.061 \\
\hline Operative side, $\mathrm{R} / \mathrm{L}$ & $27 / 13$ & $24 / 16$ & $23 / 16$ & 0.693 \\
\hline Height (cm) & $160.6 \pm 8.7$ & $161.6 \pm 7.5$ & $160.3 \pm 8.5$ & 0.762 \\
\hline Weight (kg) & $61.9 \pm 12.3$ & $60.2 \pm 11.3$ & $60.8 \pm 9.9$ & 0.784 \\
\hline $\mathrm{BMI}\left(\mathrm{kg} / \mathrm{m}^{2}\right)$ & $23.9 \pm 4.0$ & $22.9 \pm 3.1$ & $23.6 \pm 2.9$ & 0.403 \\
\hline ASA score $|/||/|||$ & $3 / 29 / 8$ & $2 / 25 / 13$ & $6 / 27 / 6$ & 0.170 \\
\hline $\mathrm{HHS}$ & $52.6 \pm 14.0$ & $48.9 \pm 10.1$ & $51.1 \pm 13.0$ & 0.423 \\
\hline HOOS & & & & 0.842 \\
\hline Symptoms & $10.4 \pm 2.7$ & $9.7 \pm 2.5$ & $9.9 \pm 2.8$ & 0.453 \\
\hline Pain & $20.1 \pm 5.1$ & $19.2 \pm 5.0$ & $19.9 \pm 5.2$ & 0.731 \\
\hline Daily living & $30.4 \pm 6.3$ & $29.0 \pm 6.3$ & $28.7 \pm 7.2$ & 0.647 \\
\hline Sports and recreational activities & $5.3 \pm 1.3$ & $5.0 \pm 1.3$ & $5.6 \pm 1.6$ & 0.177 \\
\hline Quality of life & $5.0 \pm 1.8$ & $4.6 \pm 1.6$ & $4.9 \pm 1.7$ & 0.568 \\
\hline Movement VAS & $4.1 \pm 1.3$ & $4.4 \pm 0.7$ & $4.5 \pm 0.9$ & 0.176 \\
\hline Resting VAS & $0.7 \pm 0.7$ & $0.7 \pm 0.6$ & $0.7 \pm 0.5$ & 0.967 \\
\hline \multicolumn{5}{|l|}{ SF-12 } \\
\hline PCS & $14.8 \pm 2.8$ & $13.8 \pm 2.6$ & $14.4 \pm 2.2$ & 0.195 \\
\hline MCS & $21.4 \pm 2.9$ & $21.1 \pm 1.6$ & $22.2 \pm 1.6$ & 0.053 \\
\hline Duration of surgery (min) & $63.3 \pm 18.2$ & $66.8 \pm 21.0$ & $62.8 \pm 19.1$ & 0.615 \\
\hline
\end{tabular}

Values are the mean \pm SD or count as appropriate

$M$ male; F female; $R$ right; $L$ left; BMI body mass index; HHS Harris Hip Score; ASA American Society of Anesthesiologists; HOOS Hip Disability and Osteoarthritis Outcome score; VAS visual analogue scale; SF-12 the 12-Item Short Form Health Survey; PCS physical component summary; MCS mental component summary ${ }^{\dagger}$ The $p$ value represents the result of one-way analysis of variance for independent means for continuous variables or the chi-square test for independent proportions amongst the 3 groups 
Table 2 VAS scores and morphine equivalents consumption

\begin{tabular}{|c|c|c|c|c|}
\hline Variables & Group A $(n=40)$ & Group B $(n=40)$ & Group C $(n=39)$ & $P$ values* \\
\hline \multicolumn{5}{|l|}{ Resting VAS } \\
\hline $2 \mathrm{~h}$ & $2.4 \pm 0.7$ & $2.3 \pm 0.9$ & $3.4 \pm 1.0$ & $<0.001^{* *}$ \\
\hline $6 \mathrm{~h}$ & $2.3 \pm 0.6$ & $2.1 \pm 0.6$ & $2.9 \pm 0.7$ & $<0.001^{* *}$ \\
\hline $12 \mathrm{~h}$ & $2.2 \pm 0.8$ & $2.0 \pm 0.5$ & $2.6 \pm 0.8$ & $0.002^{* *}$ \\
\hline $24 \mathrm{~h}$ & $1.8 \pm 0.4$ & $1.8 \pm 0.6$ & $1.8 \pm 0.5$ & 0.834 \\
\hline $36 \mathrm{~h}$ & $1.7 \pm 0.6$ & $1.6 \pm 0.6$ & $1.6 \pm 0.6$ & 0.850 \\
\hline $48 \mathrm{~h}$ & $1.2 \pm 0.4$ & $1.2 \pm 0.4$ & $1.3 \pm 0.6$ & 0.268 \\
\hline $60 h^{\#}$ & $1.1 \pm 0.3$ & $1.1 \pm 0.3$ & $1.3 \pm 0.5$ & 0.153 \\
\hline $72 h^{\#}$ & $1.1 \pm 0.3$ & $1.0 \pm 0.2$ & $1.2 \pm 0.4$ & 0.122 \\
\hline \multicolumn{5}{|l|}{ Movement VAS } \\
\hline $6 \mathrm{~h}$ & $3.8 \pm 0.7$ & $3.7 \pm 0.9$ & $4.6 \pm 0.8$ & $<0.001^{* *}$ \\
\hline $12 \mathrm{~h}$ & $3.7 \pm 0.8$ & $3.5 \pm 0.6$ & $4.2 \pm 0.9$ & $<0.001^{* *}$ \\
\hline $24 \mathrm{~h}$ & $3.3 \pm 0.5$ & $3.2 \pm 0.5$ & $3.4 \pm 0.5$ & 0.244 \\
\hline $36 \mathrm{~h}$ & $3.2 \pm 0.5$ & $3.1 \pm 0.4$ & $3.1 \pm 0.5$ & 0.474 \\
\hline $48 \mathrm{~h}$ & $2.7 \pm 0.6$ & $2.8 \pm 0.4$ & $2.9 \pm 0.8$ & 0.464 \\
\hline $60 \mathrm{~h}^{\#}$ & $2.8 \pm 0.6$ & $2.6 \pm 0.5$ & $2.9 \pm 0.3$ & 0.170 \\
\hline $72 \mathrm{~h}^{\#}$ & $2.1 \pm 0.3$ & $2.2 \pm 0.4$ & $2.3 \pm 0.5$ & 0.317 \\
\hline \multicolumn{5}{|l|}{ Morphine equivalents (mg) } \\
\hline $0-12 \mathrm{~h}$ & $2.3 \pm 5.4$ & $1.9 \pm 5.0$ & $4.2 \pm 7.7$ & 0.191 \\
\hline $0-24 h$ & $9.1 \pm 13.3$ & $9.6 \pm 14.6$ & $11.8 \pm 15.7$ & 0.688 \\
\hline Total during hospitalisation & $32.5 \pm 47.2$ & $32.1 \pm 48.2$ & $48.6 \pm 57.8$ & 0.270 \\
\hline
\end{tabular}

Values are the mean \pm SD

*From one-way analysis of variance or Kruskal-Wallis analysis for independent means for continuous variables amongst the three groups **Significant

${ }^{\#} 25 / 26 / 23$ patients in group $\mathrm{A} / \mathrm{B} / \mathrm{C}$ were in the hospital at 60 postoperative hours, and $24 / 26 / 23$ patients in group $\mathrm{A} / \mathrm{B} / \mathrm{C}$ were in the hospital at 72 postoperative hours

respectively) (Table 4). The amounts of morphine equivalent consumption at all time points as well as total consumption in groups $\mathrm{A}$ and $\mathrm{B}$ were less than those in group $\mathrm{C}$, although the differences were not significant (Table 2). Moreover, there were no significant differences in the ROM of the hip at postoperative day 2, length of hospital stay, opioid-related side effects and wound complications amongst the three groups (Tables $4,5)$.

During the 6-month follow-up period after THA, resting and movement VAS scores, Harris Hip Scores (HHS), Hip Disability and Osteoarthritis Outcome scores (HOOS) and the 12-Item Short Form Health Survey (SF-12) results amongst the three groups were not

Table 3 VAS scores post hoc test

\begin{tabular}{|c|c|c|c|c|c|c|c|}
\hline \multirow[t]{2}{*}{ Variables } & \multirow{2}{*}{$\begin{array}{l}\text { Group } \\
\text { A }(n= \\
40)\end{array}$} & \multirow{2}{*}{$\begin{array}{l}\text { Group } \\
\text { B }(n= \\
40)\end{array}$} & \multirow{2}{*}{$\begin{array}{l}\text { Group } \\
C(n= \\
39)\end{array}$} & \multicolumn{4}{|l|}{$P$ values ${ }^{+}$} \\
\hline & & & & $P$ & $P 1$ & $P 2$ & P3 \\
\hline \multicolumn{8}{|c|}{ Resting VAS } \\
\hline $2 \mathrm{~h}$ & $2.4 \pm 0.7$ & $2.3 \pm 0.9$ & $3.4 \pm 1.0$ & $<0.001^{\boldsymbol{+ +}}$ & 1.000 & $<0.001^{++}$ & $<0.001^{\boldsymbol{+ +}}$ \\
\hline $6 \mathrm{~h}$ & $2.3 \pm 0.6$ & $2.1 \pm 0.6$ & $2.9 \pm 0.7$ & $<0.001^{\boldsymbol{+ +}}$ & 0.937 & $<0.001^{\boldsymbol{+ +}}$ & $<0.001^{\boldsymbol{+ +}}$ \\
\hline $12 \mathrm{~h}$ & $2.2 \pm 0.8$ & $2.0 \pm 0.5$ & $2.6 \pm 0.8$ & $0.002^{\boldsymbol{+ +}}$ & 0.482 & 0.075 & $0.001^{++}$ \\
\hline \multicolumn{8}{|c|}{ Movement VAS } \\
\hline $6 \mathrm{~h}$ & $3.8 \pm 0.7$ & $3.7 \pm 0.9$ & $4.6 \pm 0.8$ & $<0.001^{\boldsymbol{+ +}}$ & 1.000 & $<0.001^{++}$ & $<0.001^{\boldsymbol{+ +}}$ \\
\hline $12 \mathrm{~h}$ & $3.7 \pm 0.8$ & $3.5 \pm 0.6$ & $4.2 \pm 0.9$ & $<0.001^{++}$ & 0.722 & $0.007^{\boldsymbol{+ +}}$ & $<0.001^{\boldsymbol{+ +}}$ \\
\hline
\end{tabular}

Values are the mean \pm SD

From one-way analysis of variance for independent means for continuous variables amongst the three groups. $P$ values from analysis with use of the post hoc Bonferroni test; $P p$ value of group $A$ vs $B$ vs $C ; P 1 p$ value of group $A$ vs $B ; P 2 p$ value of group $A$ vs $C ; P 3 p$ value of group $B$ vs $C$

$+{ }^{++}$Significant 
Table 4 Postoperative outcomes

\begin{tabular}{|c|c|c|c|c|c|c|c|}
\hline \multirow[t]{2}{*}{ Variables } & \multirow{2}{*}{$\begin{array}{l}\text { Group A } \\
(n=40)\end{array}$} & \multirow{2}{*}{$\begin{array}{l}\text { Group B } \\
(n=40)\end{array}$} & \multirow{2}{*}{$\begin{array}{l}\text { Group C } \\
(n=39)\end{array}$} & \multicolumn{4}{|c|}{$P$ values $^{\Delta}$} \\
\hline & & & & $\bar{P}$ & $P 1$ & $P 2$ & $P 3$ \\
\hline Hospital stay (days) & $2.9 \pm 1.0$ & $2.9 \pm 0.8$ & $2.8 \pm 0.9$ & 0.869 & & & \\
\hline \multicolumn{8}{|l|}{ Pain satisfaction $(n)$} \\
\hline Very satisfied & 25 & 26 & 15 & $0.033^{\Delta \Delta}$ & 0.816 & $0.033^{\Delta \Delta}$ & $0.018^{\Delta \Delta}$ \\
\hline Somewhat satisfied & 15 & 14 & 24 & $0.033^{\Delta \Delta}$ & 0.816 & $0.033^{\Delta \Delta}$ & $0.018^{\triangle \Delta}$ \\
\hline Somewhat dissatisfied & 0 & 0 & 0 & & & & \\
\hline Very dissatisfied & 0 & 0 & 0 & & & & \\
\hline \multicolumn{8}{|l|}{ Function satisfaction (n) } \\
\hline Very satisfied & 18 & 19 & 18 & 0.975 & 0.823 & 0.918 & 0.905 \\
\hline Somewhat satisfied & 22 & 21 & 21 & 0.975 & 0.823 & 0.918 & 0.905 \\
\hline Somewhat dissatisfied & 0 & 0 & 0 & & & & \\
\hline Very dissatisfied & 0 & 0 & 0 & & & & \\
\hline Straight leg raise $(n)$ & 31 & 28 & 18 & $0.010^{\Delta \Delta}$ & 0.446 & $0.004^{\Delta \Delta}$ & $0.032^{\Delta 1}$ \\
\hline \multicolumn{8}{|l|}{ Range of motion $\left(^{\circ}\right)$} \\
\hline Flexion & $106.0 \pm 5.8$ & $104.3 \pm 6.3$ & $103.5 \pm 6.4$ & 0.176 & & & \\
\hline Abduction & $33.3 \pm 3.7$ & $32.9 \pm 3.4$ & $33.5 \pm 3.8$ & 0.768 & & & \\
\hline Extension & 0 & 0 & 0 & & & & \\
\hline
\end{tabular}

Values are the mean \pm SD or count as appropriate

${ }^{\Delta}$ From one-way analysis of variance for independent means for continuous variables or the chi-square test for independent proportions amongst the three groups. $P p$ value of group $A$ vs $B$ vs $C ; P 1 p$ value of group $A$ vs $B ; P 2 p$ value of group $A$ vs $C ; P 3 p$ value of group $B$ vs $C$

${ }^{\Delta}$ Significant

significantly different. Only 2 patients in group C continued to take analgesic drugs 2 weeks after discharge, and no patients complained about hip pain at the last followup. No patient experienced wound complications during the follow-up period (Table 6).

\section{Discussion}

In our study, with the LIA method and analgesic protocol we used, the two LIA groups had less pain than the control group within $12 \mathrm{~h}$ after primary THA and had a higher level of patient satisfaction. Furthermore, despite the lack of a significant difference, the total morphine equivalents consumed in groups A and B were $16.1 \mathrm{mg}$ $(33.1 \%)$ and $16.5 \mathrm{mg}(34.0 \%)$ less than that consumed in group $\mathrm{C}$, respectively. In addition, the two LIA groups had comparable analgesic effects.

In previous RCTs on single-shot LIA in THA [6, 8-14, 20], there was a lack of consensus on the dosage, volume and constituents of LA, and there was controversy regarding whether single-shot LIA had a role in the multimodal analgesia regimen for THA (Table 7). Three of these RCTs used a single LA for infiltration, two of which used ropivacaine and one of which used levobupivacaine $[9,14,20]$. Zoric et al. demonstrated that $80 \mathrm{ml}$ of $0.2 \%$ ropivacaine used for LIA did not reduce opioid consumption and did not improve postoperative rehabilitation after THA [9]. In contrast, Murphy et al. showed that using $60 \mathrm{ml}$ of $0.25 \%$ levobupivacaine for

Table 5 Complications

\begin{tabular}{|c|c|c|c|c|}
\hline Variables & Group A $(n=40)$ & Group B $(n=40)$ & Group C $(n=39)$ & $P$ values ${ }^{\circledast}$ \\
\hline Nausea and vomiting & 1 & 2 & 1 & 1.000 \\
\hline Urinary retention & 2 & 1 & 0 & 1.000 \\
\hline Pruritus & 0 & 0 & 0 & \\
\hline Aseptic fat liquefaction of wound & 2 & 2 & 1 & 1.000 \\
\hline Superficial infection & 0 & 0 & 0 & \\
\hline Deep infection & 0 & 0 & 0 & \\
\hline Haematoma & 0 & 0 & 0 & \\
\hline Superficial wound necrosis & 0 & 0 & 0 & \\
\hline
\end{tabular}

Values are counts

※Chi-square or Fisher's test for independent proportions amongst the three groups 
Table 6 Follow-up outcomes

\begin{tabular}{|c|c|c|c|c|}
\hline Variables & Group A $(n=40)$ & Group B $(n=40)$ & Group C $(n=39)$ & $P$ values ${ }^{\mathbf{A}}$ \\
\hline \multicolumn{5}{|l|}{ Resting VAS } \\
\hline 2 weeks & $0.2 \pm 0.4$ & $0.2 \pm 0.4$ & $0.3 \pm 0.4$ & 0.839 \\
\hline 3 months & $0.1 \pm 0.3$ & $0.1 \pm 0.3$ & $0.1 \pm 0.3$ & 0.999 \\
\hline 6 months & $0.1 \pm 0.3$ & $0.1 \pm 0.2$ & $0.1 \pm 0.3$ & 0.704 \\
\hline \multicolumn{5}{|l|}{ Movement VAS } \\
\hline 2 weeks & $1.2 \pm 0.4$ & $1.2 \pm 0.4$ & $1.3 \pm 0.4$ & 0.932 \\
\hline 3 months & $0.7 \pm 0.7$ & $0.7 \pm 0.6$ & $0.7 \pm 0.7$ & 0.991 \\
\hline 6 months & $0.6 \pm 0.6$ & $0.5 \pm 0.6$ & $0.6 \pm 0.6$ & 0.578 \\
\hline \multicolumn{5}{|l|}{ HOOS-3 months } \\
\hline Symptoms & $16.6 \pm 1.2$ & $16.3 \pm 1.1$ & $16.1 \pm 1.1$ & 0.244 \\
\hline Pain & $31.1 \pm 1.6$ & $30.9 \pm 1.5$ & $30.5 \pm 1.7$ & 0.238 \\
\hline Daily living & $60.9 \pm 1.7$ & $61.3 \pm 1.9$ & $60.7 \pm 1.7$ & 0.420 \\
\hline Sports and recreational activities & $12.0 \pm 1.5$ & $12.5 \pm 1.4$ & $11.9 \pm 1.4$ & 0.153 \\
\hline Quality of life & $11.8 \pm 1.3$ & $12.0 \pm 1.3$ & $11.7 \pm 1.2$ & 0.455 \\
\hline HHS-3 months & $89.1 \pm 2.2$ & $88.7 \pm 2.3$ & $88.2 \pm 2.1$ & 0.213 \\
\hline \multicolumn{5}{|l|}{ SF-12-3 months } \\
\hline PCS & $22.3 \pm 1.1$ & $21.8 \pm 1.3$ & $22.0 \pm 1.2$ & 0.274 \\
\hline MCS & $26.1 \pm 1.3$ & $26.0 \pm 1.3$ & $25.9 \pm 1.4$ & 0.737 \\
\hline \multicolumn{5}{|l|}{ HOOS-6 months } \\
\hline Symptoms & $16.9 \pm 0.9$ & $17.1 \pm 0.8$ & $16.9 \pm 0.8$ & 0.467 \\
\hline Pain & $34.2 \pm 1.8$ & $33.9 \pm 1.4$ & $33.6 \pm 1.3$ & 0.336 \\
\hline Daily living & $63.5 \pm 1.4$ & $63.1 \pm 1.7$ & $63.1 \pm 1.5$ & 0.396 \\
\hline Sports and recreational activities & $13.0 \pm 1.0$ & $13.0 \pm 1.1$ & $12.7 \pm 1.1$ & 0.301 \\
\hline Quality of life & $13.0 \pm 1.1$ & $12.9 \pm 1.0$ & $12.6 \pm 0.7$ & 0.193 \\
\hline HHS-6 months & $92.1 \pm 1.9$ & $92.6 \pm 2.2$ & $92.0 \pm 2.0$ & 0.285 \\
\hline \multicolumn{5}{|l|}{ SF-12-6 months } \\
\hline PCS & $23.2 \pm 1.1$ & $23.3 \pm 1.0$ & $23.0 \pm 0.8$ & 0.291 \\
\hline MCS & $27.0 \pm 0.9$ & $27.4 \pm 1.1$ & $27.0 \pm 0.9$ & 0.092 \\
\hline
\end{tabular}

Values are the mean $\pm S D$

HHS Harris Hip Score; HOOS Hip Disability and Osteoarthritis Outcome; PCS physical component summary; MCS mental component summary

$\checkmark$ From one-way analysis of variance for independent means for continuous variables amongst the three groups

LIA in THA significantly reduced morphine consumption by $45.8 \%$ in the first $12 \mathrm{~h}$ after surgery [14]. In our study, we used $80 \mathrm{ml}$ of $0.25 \%$ ropivacaine for singleshot LIA because this dose was close to the dose authorised for infiltration in China. Our findings showed that single-shot LIA with ropivacaine alone was effective for elective primary THA. Although single-shot LIA does not improve postoperative rehabilitation in patients undergoing primary THA, it can reduce pain within $12 \mathrm{~h}$ and reduce morphine consumption by more than $30 \%$ after THA.

The LIA technique used in previous studies infiltrated all layers, including the tissues around the rim of the acetabulum, external rotators and gluteus tendon [3]. To the best of our knowledge, this study was the first to report the effect of LIA of the deep and superficial fascia in THA. Thybo et al. reported that a lateral femoral cutaneous nerve block could relieve postoperative pain due to THA via a posterolateral approach [21]. In addition, a lateral femoral cutaneous nerve block could also reduce the opioid consumption of patients undergoing femoral neck fracture surgery via a lateral incision $[16,17]$. The incision for the posterolateral approach in THA was partially located in the lateral femoral cutaneous nerve distribution area. This suggested that LIA in the deep and superficial fascia might relieve postoperative pain in patients undergoing THA surgery. Moreover, our several years' experience of applying LIA in the deep and superficial fascia in THA has demonstrated its effectiveness. In this systematic RCT, the outcomes showed that LIA in the deep and superficial fascia had a similar effect to LIA in all layers and relieved the early postoperative pain 
Table 7 Relevant RCTs regarding single-shot LIA in total hip arthroplasty

\begin{tabular}{|c|c|c|c|c|}
\hline Authors & $\begin{array}{l}\text { Study } \\
\text { design }\end{array}$ & No. of patients & LIA drugs & Conclusion \\
\hline $\begin{array}{l}\text { Busch } \\
\text { et al. [10] }\end{array}$ & $\mathrm{RCT}$ & $\begin{array}{l}\text { LIA: } 32 \text {, control: } \\
32\end{array}$ & $\begin{array}{l}\text { LIA }(100 \mathrm{ml}): 0.4 \% \text { ropivacaine }+0.03 \% \\
\text { ketorolac }+0.6: 100000 \text { epinephrine }+0.005 \% \\
\text { morphine } \\
\text { Control: not given LIA }\end{array}$ & $\begin{array}{l}\text { LIA reduces early stage postoperative pain and opioid } \\
\text { consumption after THA. }\end{array}$ \\
\hline $\begin{array}{l}\text { Liu et al. } \\
\text { [6] }\end{array}$ & $\mathrm{RCT}$ & $\begin{array}{l}\text { LIA: } 40 \text {, control: } \\
40\end{array}$ & $\begin{array}{l}\text { LIA }(60 \mathrm{ml}): 0.008 \% \text { morphine }+0.05 \% \\
\text { ropivacaine }+1.7 \% \text { betamethasone }+0.8: 100000 \\
\text { epinephrine } \\
\text { Control }(60 \mathrm{ml}) \text { : normal saline }\end{array}$ & $\begin{array}{l}\text { LIA reduces postoperative pain and opioid consumption } \\
\text { and improves postoperative rehabilitation after THA. }\end{array}$ \\
\hline $\begin{array}{l}\text { Murphy } \\
\text { et al. [14] }\end{array}$ & $\mathrm{RCT}$ & $\begin{array}{l}\text { LIA: } 45 \text {, control: } \\
46\end{array}$ & $\begin{array}{l}\text { LIA }(60 \mathrm{ml}): 0.25 \% \text { levobupivacaine } \\
\text { Control }(60 \mathrm{ml}) \text { : normal saline }\end{array}$ & LIA reduces opioid consumption after THA. \\
\hline $\begin{array}{l}\text { Villatte } \\
\text { et al. [12] }\end{array}$ & $\mathrm{RCT}$ & $\begin{array}{l}\text { LIA: } 75 \text {, control: } \\
75\end{array}$ & $\begin{array}{l}\text { LIA }(100 \mathrm{ml}): 0.235 \% \text { ropivacaine }+0.5: 100000 \\
\text { epinephrine } \\
\text { Control: not given LIA }\end{array}$ & $\begin{array}{l}\text { LIA reduces postoperative pain and opioid consumption } \\
\text { after THA. }\end{array}$ \\
\hline $\begin{array}{l}\text { Titman } \\
\text { et al. [20] }\end{array}$ & $\mathrm{RCT}$ & $\begin{array}{l}\text { LIA: } 19 \text {, control: } \\
16\end{array}$ & $\begin{array}{l}\text { LIA }(150 \mathrm{ml}): 0.2 \% \text { ropivacaine } \\
\text { Control }(150 \mathrm{ml}) \text { : normal saline }\end{array}$ & LIA reduces early-stage postoperative pain after THA. \\
\hline $\begin{array}{l}\text { Lunn } \\
\text { et al. [13] }\end{array}$ & $\mathrm{RCT}$ & $\begin{array}{l}\text { LIA: 60, control: } \\
60\end{array}$ & $\begin{array}{l}\text { LIA }(150 \mathrm{ml}): 0.2 \% \text { ropivacaine }+1: 100000 \\
\text { epinephrine } \\
\text { Control }(150 \mathrm{ml}) \text { : normal saline }\end{array}$ & $\begin{array}{l}\text { LIA does not reduce postoperative pain or opioid } \\
\text { consumption after THA. }\end{array}$ \\
\hline $\begin{array}{l}\text { Dobie } \\
\text { et al. [11] }\end{array}$ & $\mathrm{RCT}$ & LIA:50, control:46 & $\begin{array}{l}\text { LIA (200 ml): } 0.125 \% \text { Levobupivacaine }+0.5 \text { : } \\
100000 \text { epinephrine } \\
\text { Control: not given LIA }\end{array}$ & $\begin{array}{l}\text { LIA does not reduce postoperative pain and does not } \\
\text { improve postoperative rehabilitation after THA. }\end{array}$ \\
\hline $\begin{array}{l}\text { Zoric } \\
\text { et al. [9] }\end{array}$ & $\mathrm{RCT}$ & $\begin{array}{l}\text { LIA: } 27 \text {, control: } \\
24\end{array}$ & $\begin{array}{l}\text { LIA }(80 \mathrm{ml}): 0.2 \% \text { ropivacaine } \\
\text { Control }(80 \mathrm{ml}) \text { : normal saline }\end{array}$ & $\begin{array}{l}\text { LIA does not reduce opioid consumption and does } \\
\text { not improve postoperative rehabilitation after THA. }\end{array}$ \\
\hline $\begin{array}{l}\text { Hofstad } \\
\text { et al. [8] }\end{array}$ & $\mathrm{RCT}$ & $\begin{array}{l}\text { LIA: } 55 \text {, control: } \\
54\end{array}$ & $\begin{array}{l}\text { LIA }(150 \mathrm{ml}): 0.2 \% \text { ropivacaine }+0.3: 100000 \\
\text { epinephrine } \\
\text { Control }(150 \mathrm{ml}) \text { : normal saline }\end{array}$ & $\begin{array}{l}\text { LIA does not reduce postoperative pain or opioid } \\
\text { consumption after THA. }\end{array}$ \\
\hline $\begin{array}{l}\text { Current } \\
\text { study } \\
(2019)\end{array}$ & $\mathrm{RCT}$ & $\begin{array}{l}\text { Group A: } 40 \\
\text { group B: } 40, \\
\text { group C: } 39\end{array}$ & $\begin{array}{l}\text { Groups A and B ( } 80 \mathrm{ml}): 0.25 \% \text { ropivacaine } \\
\text { Group C: not given LIA }\end{array}$ & $\begin{array}{l}\text { LIA reduces early-stage postoperative pain, and LIA in the } \\
\text { deep and superficial fascia had a similar analgesic effect to } \\
\text { LIA in all layers in THA. LIA seems to help reduce opioid } \\
\text { consumption but does not improve postoperative } \\
\text { rehabilitation after THA. }\end{array}$ \\
\hline
\end{tabular}

RCT Randomised controlled trial, LIA Local infiltration anaesthesia, THA Total hip arthroplasty; group A LIA in the deep and superficial fascia group; group B LIA in all layers group; group $C$ control group

due to THA surgery via a posterolateral approach. As LIA in the deep and superficial fascia is easier to perform than LIA in all layers, it might be an alternative method.

In our study, the analgesic effects in the two LIA groups lasted $12 \mathrm{~h}$ after THA. Previous studies reported that the longest analgesic effect duration of single-shot LIA in THA was $48 \mathrm{~h}$ [14]. To prolong the analgesic effect of LIA after THA, three methods were employed. The first method was adding epinephrine to local anaesthetic. Titman et al. used $150 \mathrm{ml}$ of $0.2 \%$ ropivacaine for single-shot LIA and found that it could relieve the postoperative pain due to THA in the first hour after surgery [20]. However, Lunn et al. found that single-shot LIA with $150 \mathrm{ml}$ of a solution composed of $0.2 \%$ ropivacaine and 1:100,000 epinephrine had no effect on postoperative pain due to THA surgery [13]. Therefore, this method seems unreliable. The second method was inserting an indwelling catheter in the surgical site to facilitate the injection of local anaesthetic after the surgery. Bianconi et al. reported that injecting $0.2 \%$ ropivacaine at $5 \mathrm{ml} / \mathrm{h}$ via an indwelling catheter in the surgical site until 55 postoperative hours could prolong the analgesic effect of LIA to $72 \mathrm{~h}$ after total joint arthroplasty surgery, and the pharmacokinetic results of this study confirmed the safety of the method [22]. However, Bianconi et al. enrolled total knee arthroplasty and THA patients at the same time and did not analyse them independently. Aguirre et al. showed that this method could significantly decrease morphine consumption by $24.3 \mathrm{mg}$ (34.9\%) during the first 48 postoperative hours compared with the placebo [4]. However, Solovyova et al. demonstrated that the continuous infusion of $0.2 \%$ ropivacaine at $5 \mathrm{ml} / \mathrm{h}$ for $48 \mathrm{~h}$ after surgery provided no additional analgesic benefit in THA managed with a multimodal analgesia regimen. A similar conclusion was drawn in two other previous studies $[5,23]$. Therefore, the effect of this method needs to be verified. The third method was infiltration with sustained-release anaesthetics. EXPAREL (DepoFoam Bupivacaine) used polycystic liposomes as a carrier of bupivacaine; these liposomes could continuously release bupivacaine $72 \mathrm{~h}$ 
after a single-dose infiltration [24]. A meta-analysis performed by Zhang et al. showed that EXPAREL had a lasting analgesic effect for up to $48 \mathrm{~h}$ after THA surgery when used for LIA. Accordingly, this method is promising, but the drug is not yet widely used in China, and more research is needed to confirm its effectiveness.

In our study, two patients in group $C$ needed analgesic drugs for more than 2 weeks; nevertheless, the follow-up results at 6 months showed that LIA had no effect on the postoperative pain score and hip rehabilitation after THA surgery. Similarly, Zoric et al. found that there were no significant differences in rehabilitation progress and chronic pain between the LIA group and control group at 3 months and 1 year after THA surgery [9]. However, Aguirre et al. demonstrated that THA patients could still benefit from LIA for 3 months after surgery [4]. Further studies are needed to evaluate the long-term effect of LIA in THA.

Our study had several limitations. First, the surgeons were not blinded to the group assignment; however, the patients, care providers, analgesic drug managers and data collectors were blinded, and the surgeons did not participate in the data collection and postoperative management related to this trial. Second, all patients in this study received general anaesthesia. Spinal anaesthesia is associated with improved perioperative outcomes, although there is limited quantitative evidence [25]. Therefore, our findings may not be applicable to patients who received spinal anaesthesia. Third, this study was conducted in a single centre, and all operations were performed by the same surgeon, which might reduce the bias caused by different surgeons. However, the surgeon in this study had completed more than 3000 THAs and was proficient. Therefore, we are not sure whether surgical technique would affect the results.

In conclusion, in patients undergoing primary THA via the posterolateral approach under general anaesthesia, single-shot LIA reduces the pain score during the first 12 postoperative hours and improves patient satisfaction. Furthermore, LIA seems to help reduce opioid consumption. LIA did not have a clinical effect on rehabilitation of the hip after THA. LIA in the deep and superficial fascia and LIA in all layers have similar analgesic effects in elective THA. LIA in the deep and superficial fascia may be an alternative method to LIA in all layers as it is obviously easier to perform.

\section{Abbreviations}

THA: Total hip arthroplasty; LIA: Local infiltration anaesthesia; VAS: Visual analogue scale; ROM: Range of motion; HHS: Harris Hip scores; HOOS: Hip Disability and Osteoarthritis Outcome scores; SF-12: The 12-Item Short Form Health Survey

\section{Acknowledgements}

We would like to thank the relevant staff in our hospital who provided guidance and assistance for their support and collaboration. We thank the patients who participated in this study.

\section{Authors' contributions}

QX and BX contributed equally to this work. Z-K. Z and F-X. P conceived and designed this study; QX, H-Y. W, BX, M-C. Y and Z-Y. L collected the data; QX and BX performed the statistical analysis; QX wrote the manuscript; QX, BX and Z-K. Z revised this manuscript. All authors reviewed the final manuscript. All authors agree to be accountable for all aspects of the work.

\section{Funding}

The study was funded by Key Research \& Development program of Science \& Technology Department of Sichuan Province (No. 2018SZ0255).

\section{Availability of data and materials}

The datasets used and/or analysed during the current study are available from the corresponding author on reasonable request.

\section{Ethics approval and consent to participate}

This study was approved by the Ethics Committee and Institutional Review Board of West China Hospital, Sichuan University.

\section{Consent for publication}

Not applicable.

\section{Competing interests}

The authors declare that they have no competing interests.

\section{Author details}

'Department of Orthopedics, Chengdu Second People's Hospital, Chengdu, People's Republic of China. ${ }^{2}$ Department of Orthopedics, West China Hospital/West China School of Medicine, Sichuan University, 37\# Wuhou Guoxue Road, Chengdu 610041, People's Republic of China.

Received: 1 December 2020 Accepted: 25 December 2020

Published online: 22 January 2021

\section{References}

1. Parvizi J, Miller AG, Gandhi K. Multimodal pain management after total joint arthroplasty. J Bone Joint Surg Am. 2011;93:1075-84.

2. Tang H, Du H, Tang Q, et al. Chinese patients' satisfaction with total hip arthroplasty: what is important and dissatisfactory? J Arthroplasty. 2014;29: 2245-50.

3. Kerr DR, Kohan L. Local infiltration analgesia: a technique for the control of acute postoperative pain following knee and hip surgery: a case study of 325 patients. Acta Orthop. 2008;79:174-83.

4. Aguirre J, Baulig B, Dora C, et al. Continuous epicapsular ropivacaine $0.3 \%$ infusion after minimally invasive hip arthroplasty: a prospective, randomized, double-blinded, placebo-controlled study comparing continuous wound infusion with morphine patient-controlled analgesia. Anesth Analg. 2012; 114:456-61

5. Specht K, Leonhardt JS, Revald P, et al. No evidence of a clinically important effect of adding local infusion analgesia administrated through a catheter in pain treatment after total hip arthroplasty. Acta Orthop. 2011:82:315-20.

6. Liu W, Cong R, Li X, et al. Reduced opioid consumption and improved early rehabilitation with local and intraarticular cocktail analgesic injection in total hip arthroplasty: a randomized controlled clinical trial. Pain Med. 2011;12: 387-93

7. Solovyova O, Lewis CG, Abrams JH, et al. Local infiltration analgesia followed by continuous infusion of local anesthetic solution for total hip arthroplasty: a prospective, randomized, double-blind, placebo-controlled study. J Bone Joint Surg Am. 2013;95:1935-41.

8. Hofstad JK, Winther SB, Rian T, et al. Perioperative local infiltration anesthesia with ropivacaine has no effect on postoperative pain after total hip arthroplasty. Acta Orthop. 2015;86:654-8.

9. Zoric L, Cuvillon P, Alonso S, et al. Single-shot intraoperative local anaesthetic infiltration does not reduce morphine consumption after total hip arthroplasty: a double-blinded placebo-controlled randomized study. $\mathrm{Br}$ J Anaesth. 2014;112:722-8. 
10. Busch CA, Whitehouse MR, Shore BJ, et al. The efficacy of periarticular multimodal drug infiltration in total hip arthroplasty. Clin Orthop Relat Res. 2010;468:2152-9.

11. Dobie I, Bennett D, Spence DJ, et al. Periarticular local anesthesia does not improve pain or mobility after THA. Clin Orthop Relat Res. 2012;470:195865.

12. Villatte $G$, Engels $E$, Erivan $R$, et al. Effect of local anaesthetic wound infiltration on acute pain and bleeding after primary total hip arthroplasty: the EDIPO randomised controlled study. Int Orthop. 2016;40:2255-60.

13. Lunn $T H$, Husted $H$, Solgaard $S$, et al. Intraoperative local infiltration analgesia for early analgesia after total hip arthroplasty: a randomized, double-blind, placebo-controlled trial. Reg Anesth Pain Med. 2011;36:424-9.

14. Murphy TP, Byrne DP, Curtin P, et al. Can a periarticular levobupivacaine injection reduce postoperative opiate consumption during primary hip arthroplasty? Clin Orthop Relat Res. 2012;470:1151-7.

15. Thybo KH, Schmidt H, Hagi-Pedersen D. Effect of lateral femoral cutaneous nerve-block on pain after total hip arthroplasty: a randomised, blinded, placebo-controlled trial. BMC Anesthesiol. 2016;16:21.

16. Jones SF, White A. Analgesia following femoral neck surgery. Lateral cutaneous nerve block as an alternative to narcotics in the elderly. Anaesthesia. 1985;40:682-5.

17. Coad NR. Post-operative analgesia following femoral-neck surgery--a comparison between 3 in 1 femoral nerve block and lateral cutaneous nerve block. Eur J Anaesthesiol. 1991;8:287-90.

18. Curtis GB, Johnson GH, Clark P, et al. Relative potency of controlled-release oxycodone and controlled-release morphine in a postoperative pain model. Eur J Clin Pharmacol. 1999:55:425-9.

19. Takahashi M, Ohara T, Yamanaka H, et al. The oral-to-intravenous equianalgesic ratio of morphine based on plasma concentrations of morphine and metabolites in advanced cancer patients receiving chronic morphine treatment. Palliat Med. 2003;17:673-8.

20. Titman S, Hommel A, Dobrydnjov I, et al. The efficacy of high volume of local infiltration analgesia for postoperative pain relief after total hip arthroplasty under general anaesthesia - a randomised controlled trial. Int J Orthop Trauma Nurs. 2018;28:16-21.

21. Thybo KH, Mathiesen O, Dahl JB, et al. Lateral femoral cutaneous nerve block after total hip arthroplasty: a randomized trial. Acta Anaesthesiol Scand. 2016;60:1297-305.

22. Bianconi M, Ferraro L, Traina GC, et al. Pharmacokinetics and efficacy of ropivacaine continuous wound instillation after joint replacement surgery. Br J Anaesth. 2003;91:830-5.

23. Andersen LO, Otte KS, Husted $\mathrm{H}$, et al. High-volume infiltration analgesia in bilateral hip arthroplasty. A randomized, double-blind placebo-controlled trial. Acta Orthop. 2011;82:423-6.

24. Portillo J, Kamar N, Melibary S, et al. Safety of liposome extended-release bupivacaine for postoperative pain control. Front Pharmacol. 2014;5:90.

25. Johnson RL, Kopp SL, Burkle CM, et al. Neuraxial vs general anaesthesia for total hip and total knee arthroplasty: a systematic review of comparativeeffectiveness research. Br J Anaesth. 2016;116:163-76.

\section{Publisher's Note}

Springer Nature remains neutral with regard to jurisdictional claims in published maps and institutional affiliations.

Ready to submit your research? Choose BMC and benefit from:

- fast, convenient online submission

- thorough peer review by experienced researchers in your field

- rapid publication on acceptance

- support for research data, including large and complex data types

- gold Open Access which fosters wider collaboration and increased citations

- maximum visibility for your research: over $100 \mathrm{M}$ website views per year

At $\mathrm{BMC}$, research is always in progress.

Learn more biomedcentral.com/submissions 